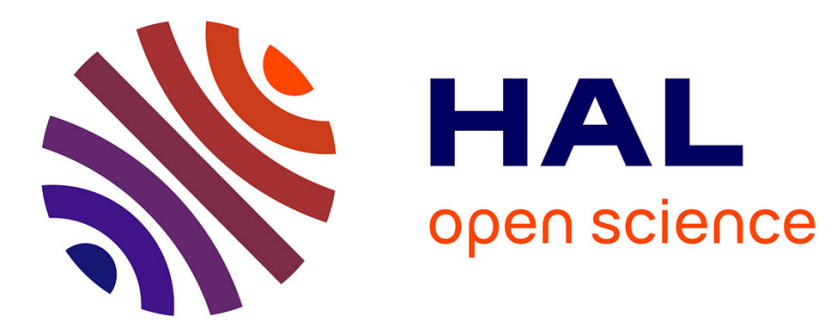

\title{
The level of the Grimsvotn subglacial lake, Vatnajokull, Iceland, monitored with SPOT5 images
}

\author{
E. Berthier, H. Bjornsson, F. Palsson, K.L. Feigl, M. Llubes, F. Remy
}

\section{To cite this version:}

E. Berthier, H. Bjornsson, F. Palsson, K.L. Feigl, M. Llubes, et al.. The level of the Grimsvotn subglacial lake, Vatnajokull, Iceland, monitored with SPOT5 images. Earth and Planetary Science Letters, 2006, 243, pp.293-302. 10.1016/j.epsl.2005.12.027 . hal-00280170

\section{HAL Id: hal-00280170 \\ https://hal.science/hal-00280170}

Submitted on 17 Jul 2009

HAL is a multi-disciplinary open access archive for the deposit and dissemination of scientific research documents, whether they are published or not. The documents may come from teaching and research institutions in France or abroad, or from public or private research centers.
L'archive ouverte pluridisciplinaire HAL, est destinée au dépôt et à la diffusion de documents scientifiques de niveau recherche, publiés ou non, émanant des établissements d'enseignement et de recherche français ou étrangers, des laboratoires publics ou privés. 


\title{
The level of the Grímsvötn subglacial lake, Vatnajökull, Iceland, monitored with SPOT5 images
}

\author{
E. Berthier ${ }^{a}, *$ H. Björnsson ${ }^{b}$ F. Pálsson ${ }^{b}$ K. L. Feigl ${ }^{c}$ \\ M. Llubes ${ }^{a}$ F. Rémy ${ }^{a}$ \\ ${ }^{\mathrm{a}} \mathrm{LEGOS/CNRS/UPS,} 18$ av. Ed. Belin, 31401, Toulouse Cedex 9, FRANCE \\ ${ }^{\mathrm{b}}$ Institute of Earth Sciences, University of Iceland, Reykjavik, ICELAND \\ ${ }^{\mathrm{c}} D T P / C N R S / U P S, 14$ av. Ed. Belin, 31400, Toulouse, FRANCE
}

\begin{abstract}
We describe the vertical displacement field of an ice shelf floating on a subglacial lake, Grímsvötn, located underneath the Vatnajökull ice cap (Iceland). The uplift is measured using the correlation of two satellite optical SPOT5 images acquired 5 days apart with similar, non-vertical incidence angles. This is the first time correlation of optical images has been used to measure vertical displacements. Our technique is suitable for mapping short-term elevation changes of glaciers. If the surface features are preserved, vertical displacements can be measured every $25 \mathrm{~m}$ with an accuracy of about $0.5 \mathrm{~m}$.

The uplift map of Grímsvötn shows that $10.9( \pm 1) \mathrm{km}^{2}$ of ice was floating between 11 and 16 August 2004. The ice shelf rose by $1.7( \pm 0.6) \mathrm{m}$ indicating that the volume of liquid water in the lake increased by $0.018( \pm 0.007) \mathrm{km}^{3}$. Our field observations show that surface melting due to meteorological processes contributed $70 \%$ of the accumulated water, hence, the rest originated from ice melted by the subglacial geothermal activity. The power required to melt $0.005 \mathrm{~km}^{3}$ (water equivalent) of basal ice in 5 days is $4000 \mathrm{MW}$. The applicability of the technique can be extended to volcanology and seismology, and even landslides or subsidence, when finer-resolution optical images become available. Applied to two pairs of images, it could solve for the 3-dimensional displacements of the Earth's surface.
\end{abstract}

Key words: Geothermal activity, subglacial hydrology, SPOT5, Iceland, image correlation

$P A C S$ :

* Corresponding author
Email address: etienne. berthier@cnes.fr (E. Berthier).

Manuscript submitted to Elsevier Science

21 December 2005 


\section{Introduction}

Exploration of subglacial hydrology on a regional scale by monitoring glacier surface displacements from space is a challenging task. The displacements of the ice surface may be due to accumulation and release of water in basal storage or water merely lubricating the bed and aiding glacier sliding. These changes in basal water content are important to monitor because they partly control glacier and ice stream dynamics $(1 ; 2)$, especially during surges $(3 ; 4)$.

Such vertical displacements have been monitored in situ at single groundbased points and along profiles by geodetic and DGPS surveying and aerial photography $(1 ; 5 ; 6 ; 7)$. During the last 15 years, satellite and airborne remote sensing techniques have captured variations in topography over large areas. These techniques include repeated profiling by laser or radar altimetry $(8 ; 9 ; 10)$, but in terms of accuracy (within few centimetres) and spatial coverage $(100 \times 100 \mathrm{~km}$ for a SAR scene) SAR interferometry (InSAR) is the most efficient technique for mapping elevation changes $(11 ; 12)$. However, with the exception of cold, high, polar areas of low accumulation rate (13), conventional InSAR cannot be applied if images are separated by more than 1 to 3 days (14). Speckle tracking alleviates this shortening in certain cases (15). In our case, on the temperate Vatnajökull ice cap, only C-Band SAR images separated by one day correlate well enough for interferometric comparison (16). On the other hand, optical images correlate over longer intervals, typically from a few days in the accumulation area to a few years in the ablation zone of temperate glaciers. Such optical images have previously been used to describe horizontal motion of glaciers $(17 ; 18)$, horizontal displacements caused by earthquakes $(19 ; 20)$, and landslides $(21)$. Here, we present the first measurement of vertical motion obtained by correlating optical images. We apply our method to determine the extent and magnitude of the uplift of a floating ice shelf during the filling of a subglacial lake (Grímsvötn) located in the interior of the Vatnajökull ice cap $\left(8200 \mathrm{~km}^{2}\right)$ in southeast Iceland. In the near future, Earth's surface elevation changes induced by earthquakes, landslides or volcanoes could also be monitored with a similar technique.

\section{Site description}

The Grímsvötn subglacial lake is situated in an ice-filled caldera at the Grímsvötn volcanic centre (Figure 1, N 64.41 ${ }^{\circ}, \mathrm{W} 17.33^{\circ}$ ). The intense geothermal activity continuously melts the ice and meltwater accumulates in the subglacial lake. Its level rises until the lake drains subglacially (at an interval of 1 to 10 years) in large floods (named jökulhlaups in Iceland) to the outwash plain Skeidarársandur (7). A 270-m-thick ice shelf floats on the lake. To the south 
and the west, the lake is confined by the steep caldera walls but can expand to the north and northeast as the water level rises $(7 ; 22)$. Moreover, ice is occasionally melted by volcanic eruptions in the Grímsvötn volcano. Its mean eruption frequency has been close to once per decade during the eight past centuries (23). The most recent eruptions took place in 1934, 1983, 1998 and November 2004.

Monitoring the lake level of Grímsvötn is essential for forecasting the timing of jökulhlaups. A non differential (navigational) GPS receiver, located at the centre of the floating ice shelf, monitors its elevation continuously (Figure 2). Precise surveys using geodetic GPS receivers are also performed about 6 times a year. From June 2003 to late October 2004, the floating ice shelf rose by $60 \mathrm{~m}$. Then, it dropped suddenly due to an abrupt drainage of the lake, leading to a jökulhlaup. An eruption of the Grímsvötn volcano started a few days later, presumably triggered by the 15-m-drop in the lake level (24). The volcano geothermal flux fills gradually the lake, whose abrupt subsidence release the overburden pressure and triggers an eruption.

Observations of the area of the floating ice cover are required for estimating the lake volume and, consequently, the size of the outburst floods. After the lake drains in a jökulhlaup, the areal extent of the ice shelf can be delineated by the outermost crevasses which are formed when the ice shelf abruptly subsides (22). Yet, this a posteriori approach cannot forecast the amount of water to be released. A previous study has used InSAR from the ERS satellites tandem mission to map the extent and rate of the uplift during the period 19961999 (7). Since the tandem mission ended, we propose a new methodology to monitor glacier surface elevation changes from satellite optical images.

\section{Methodology}

Our method uses the correlation of two optical SPOT5 images to measure their offsets in the line and column directions and then derive the vertical component of the displacement field. This technique measures the projection of a ground displacement $\vec{\delta}\left[\delta_{\lambda}, \delta_{\phi}, \delta_{z}\right]$ in the focal plane of the sensor (with $\lambda$ the longitude, $\phi$ the latitude, and $\mathrm{z}$ the local vertical axis). This focal plane can be defined by two unit vectors $\overrightarrow{U_{\text {lin }}}$ and $\overrightarrow{U_{\text {col }}}$ indicating the line and column directions respectively (Figure 3 ).

If $\theta$ is the incidence angle (varying by $\pm 2^{\circ}$ throughout the images) and $\alpha$ the (azimuth) angle between the line direction and the North (varying by $\pm 0.01^{\circ}$ and thus considered as constant), the coordinates of $\overrightarrow{U_{l i n}}$ and $\overrightarrow{U_{\text {col }}}$ are

$$
\overrightarrow{U_{\text {lin }}}=[-\sin \alpha,-\cos \alpha, 0]
$$




$$
\overrightarrow{U_{c o l}}=[\cos \theta \cos \alpha,-\cos \theta \sin \alpha, \sin \theta]
$$

The correlation of the satellite images measures the displacements $\delta_{c o l}$ and $\delta_{l i n}$

$$
\begin{aligned}
& \delta_{c o l}=\vec{\delta} \cdot \overrightarrow{U_{c o l}} \\
& \delta_{l i n}=\vec{\delta} \cdot \overrightarrow{U_{l i n}}
\end{aligned}
$$

If the horizontal displacements $\delta_{\lambda}$ and $\delta_{\phi}$ can be neglected, Equation 3 simply reduces to

$$
\delta_{z}=\frac{\delta_{c o l}}{\sin \theta}
$$

A purely vertical movement will thus induce an offset in the column direction (Figure 3). Furthermore, Equation 5 shows that large incidence angles increase the sensitivity to vertical motion. For the images used in this study, the $27^{\circ}$ incidence angles lead to a sensitivity of the order of 0.45 , i.e. $45 \%$ of the vertical motion should be visible in the column-offset field.

In the case of the Grímsvötn ice shelf the horizontal glacier flow is slow and mainly oriented southward such that $\delta_{\lambda}$ can be neglected, but not $\delta_{\phi}$. With these assumptions, combining Equation 3 and 4, we deduce the vertical displacement:

$$
\delta_{z}=\frac{\delta_{c o l}-\delta_{l i n} \times \cos \theta \times \frac{\sin \alpha}{\cos \alpha}}{\sin \theta}
$$

The accuracy of the ground displacements obtained by correlating two optical images is controlled mainly by the distortions between the images (25). The distortions are proportional to the ratio of the baseline $(\mathrm{B}$, the distance between the two satellite positions) to the altitude $(\mathrm{H})$ of the satellite. When correlating two images, the $B / H$ ratio measures the apparent horizontal displacement that will be induced by an error in the digital elevation model (DEM) of the area (19). In an optimal satellite configuration, the two images are acquired from exactly the same viewpoint, the value of $B / H$ is small (typically less that 0.01 ) and the offsets in column only reflect the surface elevation changes. Favorable situation occurs when the time separation between the image dates is a multiple of the orbital cycle duration, i.e. 26 days in the case of the SPOT5 satellite. In such a satellite configuration (called an exact repeat pair), accurate measurements of surface displacements can be obtained even with a very coarse DEM, as demonstrated previously (25). 


\section{Measurements. Spatial extent of the uplift}

We have mapped the uplift of the Grímsvötn ice shelf by correlating two SPOT5 images acquired on 11 and 16 August 2004 (Table 1) with a ground resolution of $2.5 \mathrm{~m}$. Their footprints are drawn in Figure 1. They have the lowest possible gain (1 for SPOT5) which is crucial to avoid radiometric saturation of the sensor on the reflective surface of the glacier. For our study, we could not obtain satellite image pairs separated by exactly one 26-day SPOT5 orbital cycle due to cloud coverage and satellite scheduling. Furthermore, in 26 days, changes on the glacier surface could degrade the image correlation, especially in the upper accumulation area. Consequently, we apply our methodology to images acquired 5 days apart from slightly different viewpoints, with a $B / H$ ratio of 0.064 . In this case, an error of $10 \mathrm{~m}$ in the DEM would create an apparent horizontal displacement (in the image column direction) of $0.64 \mathrm{~m}$, equivalent to a vertical displacement of $1.42 \mathrm{~m}$. An accurate DEM of the ice cap is thus required.

We have calculated a DEM from a second pair of SPOT5 images acquired on 7 and 9 October 2004 (Table 1). These images have a similar footprint as the 16 August image (Figure 1). Only a $5 \mathrm{~m}$ resolution is available due to sensor problems. The two days time separation ensures a good correlation between the images even in the snow-covered region. The glacier flow in the slow moving area surrounding the Grímsvötn caldera during two days is small enough to avoid a systematic bias in the DEM. Errors or gaps could also result from the change in the length of the shadows due to the different acquisition times of the two images (at 13:25 on 7 October and 12:23 on 9 October), in particular close to the steep caldera walls to the south and the west of the ice shelf. The $B / H$ is close to 1 and optimal for elevation mapping of the smooth topography of the ice cap. The accuracy of our DEM is assessed by comparing its elevation with a kinematic GPS survey in a vehicle driving on the glacier in late September 2004. The accuracy of the kinematic GPS measurement is of the order of $\pm 0.15 \mathrm{~m}$. For the 13800 comparison points, the SPOT5 DEM is $0.75 \mathrm{~m}$ lower than the GPS data, with a RMS scatter of $7.8 \mathrm{~m}$. On the Grimsvötn ice shelf itself, our DEM has been corrected for the vertical displacement occurring between mid-August (date of the images used to map the uplift) and early October. The permanent GPS station on the ice shelf indicates an uplift of $4.5 \mathrm{~m}$ during this period. An error of $10 \%$ in this correction, which relies on extrapolating the GPS measurement to the entire ice shelf, would alter the vertical displacement measurement by less than a decimeter.

Figure 4 depicts the surface elevation changes measured by comparing the 2004 DEM with an older DEM, produced by airborne InSAR images acquired in August 1998 (26). The accuracy of the 1998 DEM is 2 to $3 \mathrm{~m}$ over the 
glacier surface. The differential DEM provides a measurement of the long term elevation change of the Grímsvötn ice shelf. The ice shelf was $55 \mathrm{~m}$ higher in 2004 than in 1998, albeit several drainage events during the 6 years (see the upper panel in Figure 2). Our map shows glacier thickening of 30 to $40 \mathrm{~m}$ in the northern Grímsvötn and Gjálp areas due to inflow of ice to the depression created by the Gjálp eruption in 1996 (27). Farther from the depression, thinning of the glacier is detected. This inflow has been monitored and modelled with $\operatorname{InSAR}(12 ; 28)$.

Using the 2004 DEM, we co-register and correlate the satellite images acquired in August (25). From homologous points extracted automatically on the stable (off glacier) area, the 16 August image is resampled in the geometry of the 11 August image. The area covered by both SPOT5 images (Figure 1) contains very few stationnary points. The homologous points are extracted far away from our area of interest, which slightly degrades the co-registration of the two images.

The correlation of the 11 August image with the resampled 16 August image is performed every 10 pixels using windows of 21 by 21 pixels. Conversion of offsets in image geometry to ground displacements takes into account the varying pixel size across the image. Noise in the displacement maps is due to noise in the DEM and changes at the glacier surface. Around the Grímsvötn ice shelf, the mean offsets in the image line direction are small (0.1 pixel) and slightly positive (not shown). They indicate a mean southward velocity of $14 \mathrm{~m} / \mathrm{a}$, slightly smaller than the $20 \mathrm{~m} / \mathrm{a}$ measured at the ground-based GPS station. Offsets in the column direction have to be corrected for a long wavelength bias. We attribute this bias to the difficulty of co-registering the two satellite images from homologous points located on the edges of the images, far away from our area of interest. This bias could also result from errors in the DEM. Because we are only interested in the relative displacement of the floating ice shelf compared to its surroundings, we account for this bias by removing from the column offset field a first-order polynomial which approximates the column offsets outside the ice shelf (20). The displacements in the column and lines directions are then converted into vertical displacement using Equation 6. The result maps the uplift of the ice shelf between 11 and 16 August (Figure 5).

This map indicates a clear uplift zone with positive vertical displacements of 1.5 to 2 meters. The uplift seems to be stronger in the margin (about 2 meters) than on the center (around 1.5 meters) of the ice shelf. We cannot conclude whether this is a real feature, because an error of 3 to 4 meters in the DEM is sufficient to explain this difference. This map is used to delimitate the extent of the uplift zone. The boundaries are displayed on both the SPOT5 image (left panel) and the vertical displacement field (right panel) in Figure 5 . We deduce that the area affected by the uplift covers $10.9 \mathrm{~km}^{2}( \pm 1) \mathrm{km}^{2}$. 
The uncertainty $\left( \pm 1 \mathrm{~km}^{2}\right)$ is estimated by delimitating twice the uplift zone: an inner and outer limits are drawn and compared. These two values differ mainly in the southeast part of the ice shelf where gaps in the DEM (due to the shadows of the $300 \mathrm{~m}$ high caldera walls) were filled by interpolation. Over this step-like topography, our interpolation leads to an overestimation of the altitude of the ice shelf, which, considering the geometry of the SPOT5 images, results in an overestimation of the uplift (in red in the left panel of Figure 5).

Over this $10.9 \mathrm{~km}^{2}$ area, the mean uplift is $1.7 \mathrm{~m}$ with a standard deviation of $\pm 0.6 \mathrm{~m}$. This standard deviation includes both measurement uncertainty and uplift variability over the ice shelf. The mean uplift corresponds to a displacement in the column direction of 0.3 pixels. This signal is only slightly larger than the (conservative) accuracy of \pm 0.2 pixels found in a previous application of our technique (25). As already noted, the main source of uncertainty in our map is the errors in the DEM. Errors could also originate from subtracting the first-order polynomial, neglecting horizontal ice flow in longitude $\left(\delta_{\lambda}\right)$ or from the biases introduced by the image correlation itself.

A permanent survey station located on the ice shelf (named MAST) provides two ground-based elevation measurements. A standard GPS receiver measures the elevation every 10 minutes. Since differential processing is not possible, the error of an individual measurement is \pm 5 to $20 \mathrm{~m}$. Comparison with DGPS measurements indicates an uncertainty of $\pm 2 \mathrm{~m}$ for the daily average. Another estimate is provided by standard barometric altimetry between one station on the ice shelf (MAST) and another on the mountain Grimsfjall, $3 \mathrm{~km}$ southeast of MAST (Figure 5). Barometric pressure and temperature are recorded every hour at both stations. The sites are affected by high winds, and inverse temperature gradients. The uncertainty in this estimation of the elevation difference between the two stations is therefore high, \pm 2 to $5 \mathrm{~m}$ depending on atmospheric conditions.

In Table 2, we compare the different uplift rates and determine if their difference is statiscally significant. Different time intervals are investigated. The difference between GPS and barometric altimetry measurements show that estimating a mean uplift rate for a short-time interval from our ground data is not robust. The two ground-based uplift rates agree only when the time interval is as much as 35 days. In this case, at the $95 \%$ confidence interval, the ground uplift rates $0.18 \pm 0.03$ and $0.19 \pm 0.02 \mathrm{~m} /$ day are not significantly smaller than the $0.23 \pm 0.1 \mathrm{~m} /$ day obtained from satellite data. Thus, assuming a constant uplift rate over one month, a good agreement is found between satellite and ground measurements.

The satellite-derived uplift rate $(0.23 \pm 0.1 \mathrm{~m} /$ day $)$ is also in good agreement with the maximum rates measured with InSAR during the period 1996-1999 
(12). The extent and the shape of the subglacial lake determined by correlating SPOT5 images agree well with the one determined previously $(12 ; 22)$.

\section{Discussion}

Our results allow a discussion of the water and energy balance of the subglacial lake. During our 5-day observation interval in August 2004, the mean lake level rose by $1.7 \mathrm{~m}$ over a $10.9 \mathrm{~km}^{2}$ area indicating that $0.018( \pm 0.007) \mathrm{km}^{3}$ of water was added to the subglacial lake. Water originated from surface and basal melting. The contribution of surface melting is deduced from ground observations.

Field mass balance measurements are performed yearly in the Grimsvötn glacier drainage basin at several sites using classic methods of snow coring for winter balance and stakes reading for summer balance (more than 30 stakes). Digital maps are constructed of the winter, summer and net balance and the total surface melting in the Grimsvötn water catchment was found by integrating over the summer balance map (29). Continous ultra-sonic measurements of local surface elevation indicates that ablation is constant throughout the summer season and, averaged over the $200 \mathrm{~km}^{2}$ of the Grimsvötn water drainage basin, amount to $1.3 \mathrm{~cm}$ (water equivalent)/day. Thus, over a 5-day interval, surface melting contributed about $0.013 \mathrm{~km}^{3}$ of water to the lake.

The remaining $0.005 \mathrm{~km}^{3}$ is due to melting of basal ice by geothermal heat in the 50 to $60 \mathrm{~km}^{2}$ surrounding the lake $(22 ; 30)$. The power required to melt this much ice in 5 days is 4000 MW, yielding an average geothermal flux of the order of $70 \mathrm{~W} \mathrm{~m}{ }^{-2}$. These estimates of the total power and the geothermal flux are a factor of 1.5 to 2 higher than values over the period 1960-1991 (22). Although our short-term estimates are uncertain, they might suggest that basal meltwater from the Gjálp eruption site of 1996 drains to the lake, leading to an overestimate of the ice melted into the Grímsvötn area.

Assuming a vertical wall bordering the lake we can assess an upper limit of the total water volume $\left(\mathcal{V}_{\text {lake }}\right)$ contained in Grímsvötn

$$
\mathcal{V}_{\text {lake }}=\left(\mathcal{Z}_{\text {iceshelf }}-\mathcal{Z}_{\text {grounded }}\right) \times \mathcal{S}_{\text {SPOT5 }}
$$

where $\mathcal{Z}_{\text {iceshelf }}$ stands for the elevation of the ice shelf, $\mathcal{Z}_{\text {grounded }}$ the elevation of the ice shelf when it is grounded (dashed horizontal line in Figure 2) and $\mathcal{S}_{\text {SPOT5 }}$ the surface area of the lake estimated by SPOT5 correlation. $\mathcal{V}_{\text {lake }}$ amounted to $0.74 \mathrm{~km}^{3}$ in mid-August 2004 .

From a methodological point of view, this study permits discussion of dif- 
ferent ways to measure elevation changes of glacier surfaces. First, long-term elevation changes can be monitored using differential DEM (Figure 4). The compared DEM can be from various origins (optical satellite images, SAR images, aerial photographs) and the accuracy of the elevation change measurement will be directly controlled by the accuracy of each individual DEM. With DEM derived from SPOT satellite optical images, an accuracy of $\pm 2 \mathrm{~m}$ can be reached (31). On the other hand, we obtain a better accuracy by correlating SPOT5 images acquired with similar, large incidence angles. The similar viewpoint limits the impact of topographic errors, whereas the large incidence angles increase the sensitivity to the vertical motion occurring between the two acquisition dates.

The main limitation of this new methodology is the need for good correlation between the two images which requires limited changes of the surface features. Over glacier surfaces, good correlations have been reported in the lower ablation zone for summer images separated by as much as one year (18). In the upper accumulation zone, typically, correlation breaks down if the images are separated by more than a few weeks due to snowdrift and snowfall. For example, over the Grímsvötn ice shelf, no results could be obtained by correlating the 11 August image with another SPOT5 image acquired 6 weeks later, on 26 September.

In our case, the slightly different incidence angles of the correlated images implied the use of a precise and contemporous DEM. In other case studies, such ancillary data may not be available. However, if the correlation remains high after at least 26 days (one orbital cycle of SPOT5), this disadvantage could be avoided by using images acquired from the same viewpoint. In such a case, even a very coarse DEM such as GTOPO-30 would suffice.

This technique could also provide a full 3-dimensional description of the displacement field. By correlating two optical images, we measure two of the three components of the displacement vector. Equations 3 and 4 constitute thus a system of two equations with three unknowns $\left[\delta_{\lambda}, \delta_{\phi}, \delta_{z}\right]$. In this study, the system could be solved because $\delta_{\lambda}$ can be neglected. In general, an independent measurement of at least one non-parallel component of the same displacement field is required to solve the system (13). This additional measurement could be provided by InSAR, but the SAR images need to span the same time interval and this technique is not applicable to temperate glaciers. We propose in Figure 6 an optical satellite configuration that would increase the sensitivity to vertical motion and resolve the $3 \mathrm{D}$ component of the surface motion. The image correlation is applied to two image pairs acquired from front and back looking position of the satellite. Some sensors, like HRS on board the SPOT5 satellite, could perform this measurement but, to our knowledge, their raw data are not available to the public. The ASTER sensor on board TERRA also presents some stereoscopic capabilities but its resolution and orbital con- 
trol are not good enough to monitor vertical motion rarely exceeding a few meters.

In this satellite configuration, the displacements in lines and columns are measured twice from two different viewpoints. Four measurements are available to determine the three components of the displacement vector; no assumption on the horizontal flow is needed.

In the case of purely vertical motion, the vertical displacement is given by

In the case of purely vertical motion, the vertical displacement is given by

$$
\delta h=\frac{\delta \operatorname{lin}_{\text {front }}-\delta \operatorname{lin}_{\text {back }}}{2 \sin \theta}
$$

If the incidence angle ( $\theta$ in Figure 6 ) is $20^{\circ}$ (as for the HRS system), $70 \%$ of the vertical displacement would be measured by the image correlation versus $45 \%$ for our measurement of the Grímsvötn ice shelf uplift. Thus, a higher precision can be expected.

\section{Conclusions}

In this study, we have measured ice rising at an average rate of about 23 $( \pm 10) \mathrm{cm} /$ day above a $10.9( \pm 1) \mathrm{km}^{2}$ subglacial lake in southeast Iceland. This uplift of the floating ice shelf is due to the addition of $0.018( \pm 0.007)$ $\mathrm{km}^{3}$ of water in the Grimsvötn lake located over a geothermal area in the central part of the Vatnajökull ice cap. Using ground measurements, we have determined the partitionning between surface and basal melting. During our 5-day observational interval, we estimated that about two third of the water added to the lake originated from the surface whereas one third was due melting of basal ice. The power required to melt $0.005 \mathrm{~km}^{3}$ of ice in 5 days is $4000 \mathrm{MW}$.

The correlation of SPOT5 images is found to be a useful method to observe vertical motions of glaciers. The technique has the potential to detect new areas of subglacial geothermal activity. Such areas are important for the assessment of natural hazards in volcanic regions. As a supplement to others remote sensing methods (10), it may contribute to regional studies of subglacial hydrology and its relation to glacier dynamics. In a broader perspective, our technique is not restricted to glacier surfaces and could also monitor any elevation changes of the Earth's surface, such as those induced by earthquakes, landslides or volcanic activity. Our scalar measurement of the Grímsvötn elevation changes is based on one pair of images. If two image pairs from a satellite with along- 
track stereo capabilities were available, it would be possible be to solve for the 3- dimensional vector displacements.

\section{Acknowledgements}

Hélène Vadon (CNES, Toulouse) provided useful help concerning the SPOT5 geometry. We thank Jørgen Dall (EMI, Technical University of Denmark) and Eyjólfur Magnússon for processing and providing the EMISAR 1998 DEM. SPOT5 images were acquired thanks to the ISIS program (copyright CNES). This work was supported by the French embassy in Iceland, the University of Iceland Research Fund, the Science Fund of Iceland (Rannís) and the Icelandic Road Authority Research Fund. GMT software (32) illustrated the article. The first author gratefully acknowledges a thesis fellowship from the French Government. 


\section{References}

[1] A. Iken, H. Röthlisberger, A. Flotron, W. Haeberli, The uplift of Unteraargletscher at the beginning of the melt season - a consequence of water storage at the bed?, J. Glaciol. 29 (101) (1983) 28-47.

[2] J. Zwally, W. Abdalati, T. Herring, K. Larson, J. Saba, K. Steffen, Surface melt-induced acceleration of Greenland ice-sheet flow, Science 297 (5579) (2002) 218-222, doi: 10.1126/science.1072708.

[3] B. Kamb, C. Raymond, W. Harrison, H. Engelhardt, K. Echelmeyer, N. Humphrey, M. Brugman, T. Pfeffer, Glacier surge mechanism: 19821983 surge of Variegated Glacier, Alaska, Science 227 (1985) 469-479.

[4] H. Björnsson, Hydrological characteristics of the drainage system beneath a surging glacier, Nature 395 (1998) 771-774.

[5] B. Kamb, H. Engelhardt, Waves of accelerated motion in a glacier approaching surge: The mini-surges of Variegated glacier, Alaska, U.S.A., J. Glaciol. 33 (113) (1987) 27-46.

[6] W. D. Harrison, K. A. Echelmeyer, H. Engelhardt, Short-period observations of speed, strain and seismicity on Ice Stream B, Antarctica., J. Glaciol. 39 (133) (1993) 463-470.

[7] H. Björnsson, Subglacial lakes and jökulhlaups in Iceland, Global Planet. Change 35 (2002) 255-271.

[8] K. A. Echelmeyer, W. D. Harrison, C. F. Larsen, J. Sapiano, J. E. Mitchell, J. DeMallie, B. Rabus, G. Adalgeirsdòttir, L. Sombardier, Airborne surface profiling of glaciers: a case-study in Alaska, J. Glaciol. 42 (142) (1996) 538-547.

[9] F. Rémy, P. Shaeffer, B. Legrésy, Ice flow physical processes derived from the ERS-1 high-resolution map of the Antarctica and Greenland ice sheets, Geophys. J. Int. 139 (3) (1999) 645-656.

[10] J. Zwally, B. Schutz, et al., ICESat's laser measurements of polar ice, atmosphere, ocean, and land, J. Geodyn. 34 (2002) 405-445.

[11] D. Massonnet, K. Feigl, Radar interferometry and its application to changes in the Earth's surface, Rev. Geophys. 36 (4) (1998) 441-500.

[12] H. Björnsson, H. Rott, S. Gudmundsson, A. Fischer, A. Siegel, M. T. Gudmundsson, Glacier-volcano interactions deduced by SAR interferometry, J. Glaciol. 47 (156) (2001) 58-70.

[13] A. L. Gray, I. Joughin, S. Tulaczyk, V. B. Spikes, R. Bindschadler, K. C. Jezek, Evidence for subglacial water transport in the West Antarctic Ice Sheet through three-dimensional satellite radar interferometry, Geophys. Res. Lett. 32 (L03501), doi:10.1029/2004GL021387.

[14] T. Strozzi, A. Luckman, T. Murray, U. Wegmüller, C. Werner, Glacier motion estimation using SAR offset-tracking procedures, IEEE T. Geosci. Remote 40 (11) (2002) 2384-2391.

[15] I. Joughin, Ice-sheet velocity mapping: A combined interferometric and speckle tracking approach, Ann. Glaciol. 34 (2002) 195-201.

[16] A. Fischer, H. Rott, H. Björnsson, Observation of recent surges of Vat- 
najökull, Iceland, by means of ERS SAR interferometry, Ann. Glaciol. 37 (2003) 69-76.

[17] T. A. Scambos, M. J. Dutkiewicz, J. C. Wilsoni, R. A. Bindschadler, Application of image cross-correlation to the measurement of glacier velocity using satellite image data, Remote Sensing Environ. 42 (3) (1992) $177-186$.

[18] A. Kääb, Combination of SRTM3 and repeat ASTER data for deriving alpine glacier flow velocities in the Bhutan Himalaya, Remote Sensing Environ. 94 (4) (2005) 463-474.

[19] N. Van Puymbroeck, R. Michel, R. Binet, J. P. Avouac, J. Taboury, Measuring earthquakes from optical satellite images, Appl. Opt. 39 (20) (2000) 3486-3494.

[20] H. Vadon, D. Massonnet, Earthquake displacement fields mapped by very precise correlation: complementary with radar interferometry, in: I. Periodicals (Ed.), IEEE International Geoscience Remote Sensing Symposium, New Jersey, 2000, pp. 2700-2702.

[21] C. Delacourt, P. Allemand, B. Casson, H. Vadon, Velocity field of the "La Clapière" landslide measured by the correlation of aerial and QuickBird satellite images, Geophys. Res. Lett. 31 (15) (2004) L15619.

[22] H. Björnsson, T. M. Gudmundsson, Variations in the thermal output of the subglacial Grimsvtön caldera, Iceland, Geophys. Res. Lett. 20 (19) (1993) 2127-2130.

[23] G. Larsen, M. T. Gudmundsson, H. Björnsson, Eight centuries of periodic volcanism at the center of the Iceland hot spot revealed by glacier tephrastratigraphy, Geology 26 (10) (1998) 943-946.

[24] F. Sigmundsson, E. Sturkell, V. Pinel, P. Einarsson, R. Pedersen, H. Geirsson, M. T. Gudmundsson, H. Björnsson, C. Pagli, Deformation and eruption forecasting at volcanoes under retreating ice caps: discriminating signs of magma inflow and ice unloading at Grímsvötn and Katla volcanoes, EOS Trans. AGU 85 (47), fall Meet. Suppl.

[25] E. Berthier, H. Vadon, D. Baratoux, Y. Arnaud, C. Vincent, K. L. Feigl, F. Rémy, B. Legrésy, Mountain glacier surface motion derived from satellite optical imagery, Remote Sensing Environ. 95 (1) (2005) 14-28.

[26] E. Magnússon, H. Björnsson, F. Pálsson, J. Dall, Glaciological application of InSAR topography data of W-Vatnajökull acquired in 1998, Jökull 54 (2004) 17-36.

[27] M. T. Gudmundsson, F. Sigmundsson, H. Björnsson, Ice-volcano interaction of the 1996 Gjálp subglacial eruption, Vatnajökull, Iceland, Nature 389 (1997) 954-957.

[28] E. Magnússon, H. Björnsson, J. Dall, F. Pálsson, Volume changes of Vatnajökull ice cap, Iceland, due to surface mass balance, ice flow, and subglacial melting at geothermal areas, Geophys. Res. Lett. 32 (5) (2005) L05504.

[29] H. Björnsson, F. Pálsson, T. M. Gudmundsson, H. H. Haraldsson, Mass balance of western and northern Vatnajökull, Iceland, 1991-1995, Jökull 
45 (1998) 35-58.

[30] H. Björnsson, Hydrology of ice caps in volcanic regions, 45, Soc. Sci. Isl., Reykjavík, 1988.

[31] E. Berthier, Y. Arnaud, D. Baratoux, C. Vincent, F. Rémy, Recent rapid thinning of the "Mer de glace" glacier derived from satellite optical images, Geophys. Res. Lett. 31 (17) (2004) L17401.

[32] P. Wessel, W. H. F. Smith, New, improved version of generic mapping tools released, EOS T. Am. Geophy. Un. 79 (47) (1998) 579.

[33] G. Neukum, R. Jaumann, the HRSC Co-Investigator, the Experiment Team, HRSC: the High Resolution Stereo Camera of Mars Express, ESA Special Paper 1240, available at: http://www.esa.int/esapub/pi/scientificPI.htm. 


\section{Figure captions}

\section{Figure 1}

Study area of Grímsvötn in Vatnajökull ice cap. The footprints of the SPOT5 images of 11 and 16 August 2004 are located on a digital elevation model of the ice cap whose margins are drawn in white. The thick black box shows the area displayed in the Figure 4. The inset locates the volcanic zones and the major ice caps in Iceland.

\section{Figure 2}

Elevation of the Grimsvötn floating ice shelf deduced from standard GPS, barometric pressure and sparse DGPS measurements at a single location (MAST). The upper panel displays the 1998-2004 period, the lower panel the June 2003-December 2004 period. The horizontal dashed line indicates the elevation (about $1370 \mathrm{~m}$ ) where the ice shelf is grounded. A longer time series (years 1930 to 2001) of ice shelf elevations can be found in (7).

\section{Figure 3}

Schematic vertical cross section showing how a vertical displacement between the acquisition dates of the satellite images produces an offset in the column direction. The sensitivity to the vertical displacement is proportional to the sine of the incidence angle $\theta$. The inset map view defines the azimuth $\alpha$, angle between the North and the line direction.

\section{Figure 4}

Elevation changes of the Grímsvötn and Gjálp areas for the 1998-2004 period. The differential DEM is obtained by subtracting the 1998 EMISAR DEM from the 2004 SPOT5 DEM. Positive values (red) correspond to an uplift (e.g., Grímsvötn ice shelf) or an ice thickening (e.g., the Gjálp area). Gray areas correspond to gap either in the EMISAR or in the SPOT5 DEM. The dashed black rectangle locates the area covered by Figure 5 .

\section{Figure 5}

(a) SPOT5 image of the Grímsvötn caldera acquired the 16 August 2004. The extent of the subglacial lake (white line) has been derived from the map of the uplift. The mean uplift of the ice shelf during 5 days, $1.7 \mathrm{~m}$, is estimated 
within this limit. The GPS station (MAST) on the floating ice shelf and the Grímsfjall mountain are located. (b) Map of the uplift of the Grímvötn ice shelf between the 11 and 16 August 2004. In grey, pixels were the correlation failed.

\section{Figure 6}

A potential satellite configuration for mapping the three-dimensional displacement field of the Earth's surface. We assume an along-track stereo capability similar to the HRS system on-board the SPOT5 satellite. During the first pass of the satellite $\left(t_{1}\right)$, two images are acquired along the track of the satellite from fore- and aft- looking sensors. One orbital cycle later during the second pass $\left(t_{2}\right)$, two more scenes are acquired. By correlating the images acquired from a similar point of view, one can deduce all three components of the displacement field (here the displacement of a crevasse on the surface of a glacier). Note that this figure is drawn in a vertical plane that contains the track of the satellite and lies perpendicular to the plane used in Figure 3 because we consider the case of a sensor with along-track stereo capabilities (such as ASTER or HRS or HRS-C on-board Mars Express (33)). The results presented in this article are based on the HRG sensor on board SPOT5 with across-track stereo capabilities. 


\section{Tables}

Table 1

Characteristics of the SPOT5 image pairs used in this study. $B / H$ is the ratio of the baseline (distance separating the two successive positions of the satellite) to the altitude of the satellite. High $B / H$ values are recommended for DEM computation whereas low $B / H$ values are best for motion mapping.

\begin{tabular}{lcccc}
\hline Image Pair & Pixel size & Incid. angle & $B / H$ & $\delta \mathrm{t}$ \\
\hline $11 \&$ 16 Aug. 04 & $2.5 \mathrm{~m}$ & $-27 /-26.7$ & 0.064 & 5 \\
$07 \&$ 09 Oct. 04 & $5 \mathrm{~m}$ & $-26.6 / 24.6$ & 0.95 & 2 \\
\hline
\end{tabular}

Table 2

Comparison of the barometric and GPS uplift rates (m/day) at MAST for different time intervals with the $0.23 \pm 0.1 \mathrm{~m}$ /day derived from SPOT5 images for 11-16 August. The uncertainty on the difference of two rates is $\sigma_{x-y}=\sqrt{\sigma_{x}^{2}+\sigma_{y}^{2}}$ because the compared rates are all independant. At the $66 \%$ confidence interval (respectively $95 \%$ ), two uplift rates are not significantly different when their difference is smaller then $\sigma_{x-y}$ (respectively $2^{*} \sigma_{x-y}$ ). These cases appear in bold.

\begin{tabular}{lcccc}
\hline & $11-16$ Aug. & $6-21$ Aug. & 1-26 Aug. & 27 Jul.-31 Aug. \\
\hline$\delta$ t (days) & 5 & 15 & 25 & 35 \\
\hline Baro & $0.78 \pm 0.32$ & $0.24 \pm 0.06$ & $0.19 \pm 0.03$ & $0.19 \pm 0.02$ \\
\hline GPS & $-0.25 \pm 0.6$ & $-0.02 \pm 0.1$ & $0.05 \pm 0.05$ & $0.18 \pm 0.03$ \\
\hline Baro - GPS & $1.03 \pm 0.68$ & $0.26 \pm 0.12$ & $0.14 \pm 0.06$ & $\mathbf{0 . 0 1} \pm \mathbf{0 . 0 3}$ \\
\hline SPOT5 - Baro & $-0.55 \pm 0.33$ & $\mathbf{0 . 0 1} \pm \mathbf{0 . 1 2}$ & $\mathbf{0 . 0 4} \pm \mathbf{0 . 1}$ & $\mathbf{0 . 0 3} \pm \mathbf{0 . 1}$ \\
\hline SPOT5 - GPS & $0.48 \pm 0.61$ & $0.25 \pm 0.14$ & $0.18 \pm 0.11$ & $\mathbf{0 . 0 5} \pm \mathbf{0 . 1}$ \\
\hline
\end{tabular}




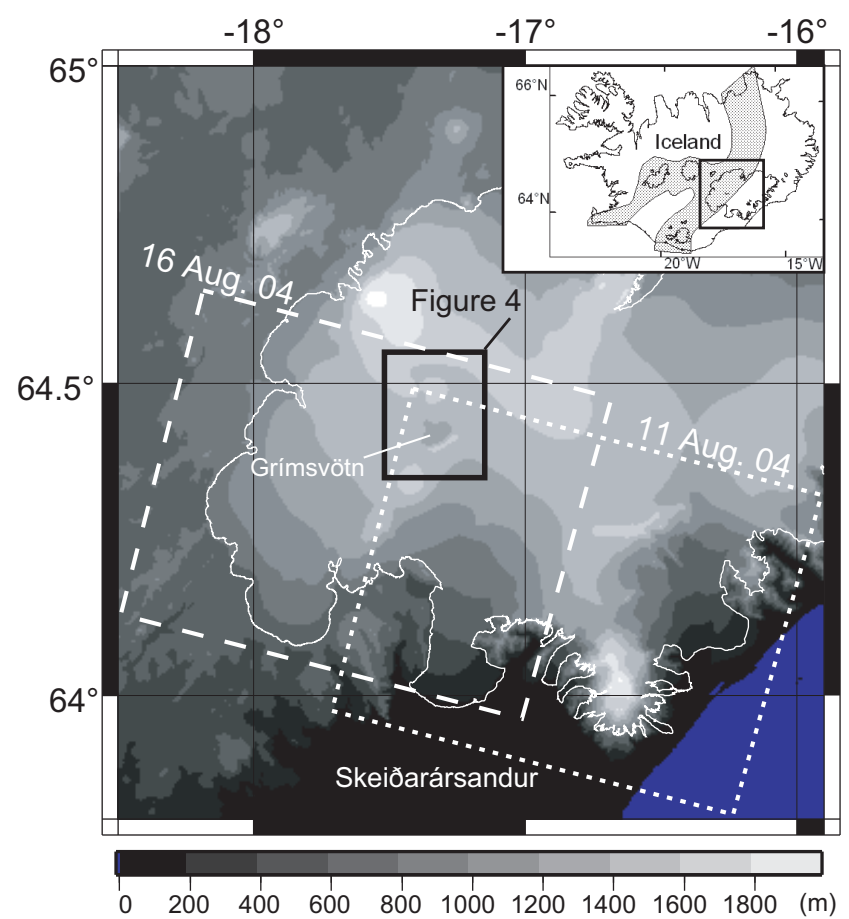

Fig. 1. Study area of Grímsvötn in Vatnajökull ice cap. The footprints of the SPOT5 images of 11 and 16 August 2004 are located on a digital elevation model of the ice cap whose margins are drawn in white. The thick black box shows the area displayed in the Figure 4. The inset locates the volcanic zones and the major ice caps in Iceland. 

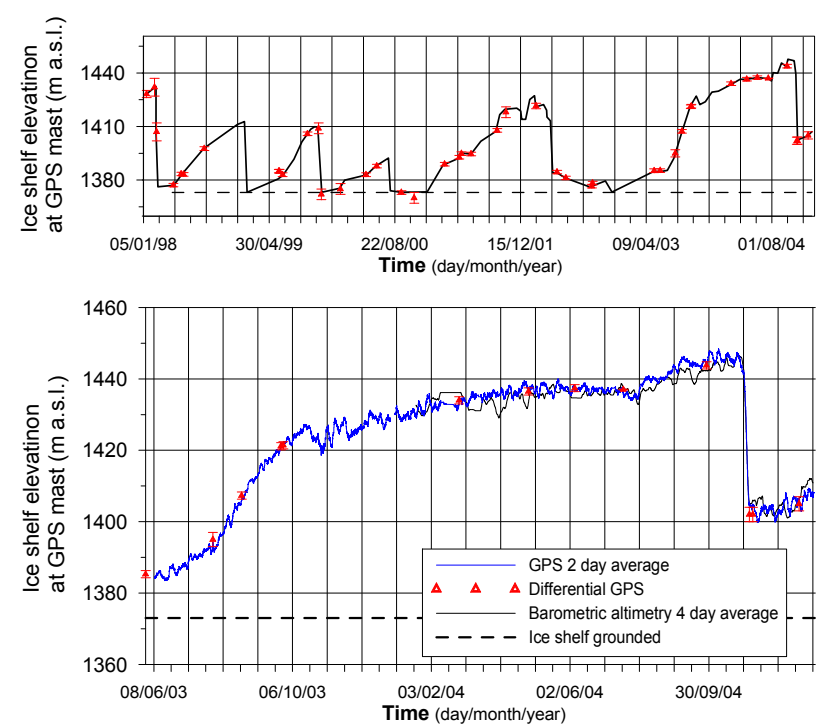

Fig. 2. Elevation of the Grímsvötn floating ice shelf deduced from standard GPS, barometric pressure and sparse DGPS measurements at a single location (MAST). The upper panel displays the 1998-2004 period, the lower panel the June 2003-December 2004 period. The horizontal dashed line indicates the elevation (about $1370 \mathrm{~m}$ ) where the ice shelf is grounded. A longer time series (years 1930 to 2001) of ice shelf elevations can be found in (7). 


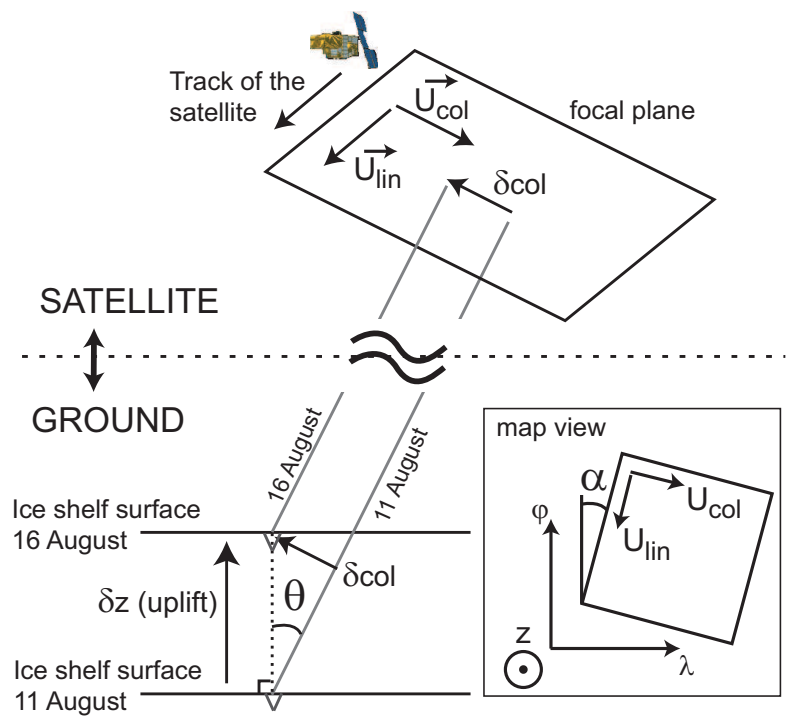

Fig. 3. Schematic vertical cross section showing how a vertical displacement between the acquisition dates of the satellite images produces an offset in the column direction. The sensitivity to the vertical displacement is proportional to the sine of the incidence angle $\theta$. The inset map view defines the azimuth $\alpha$, angle between the North and the line direction. 


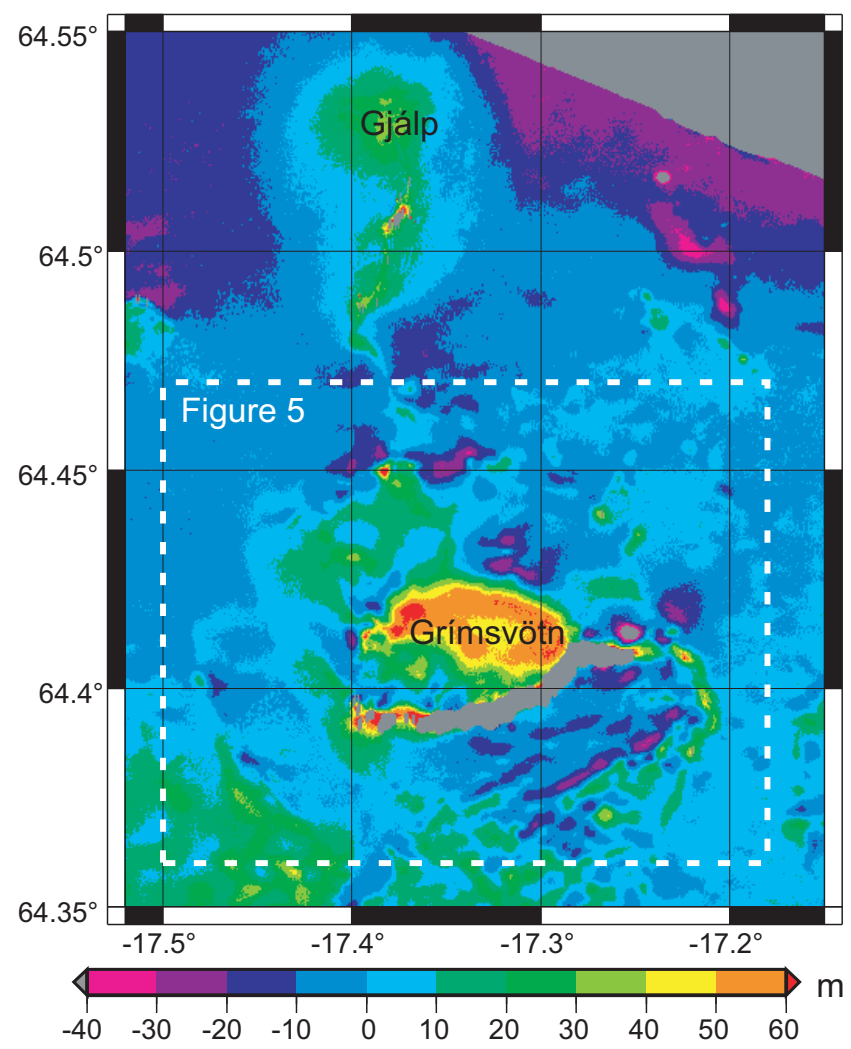

Fig. 4. Elevation changes of the Grímsvötn and Gjálp areas for the 1998-2004 period. The differential DEM is obtained by subtracting the 1998 EMISAR DEM from the 2004 SPOT5 DEM. Positive values (red) correspond to an uplift (e.g., Grímsvötn ice shelf) or an ice thickening (e.g., the Gjálp area). Gray areas correspond to gap either in the EMISAR or in the SPOT5 DEM. The dashed black rectangle locates the area covered by Figure 5 . 


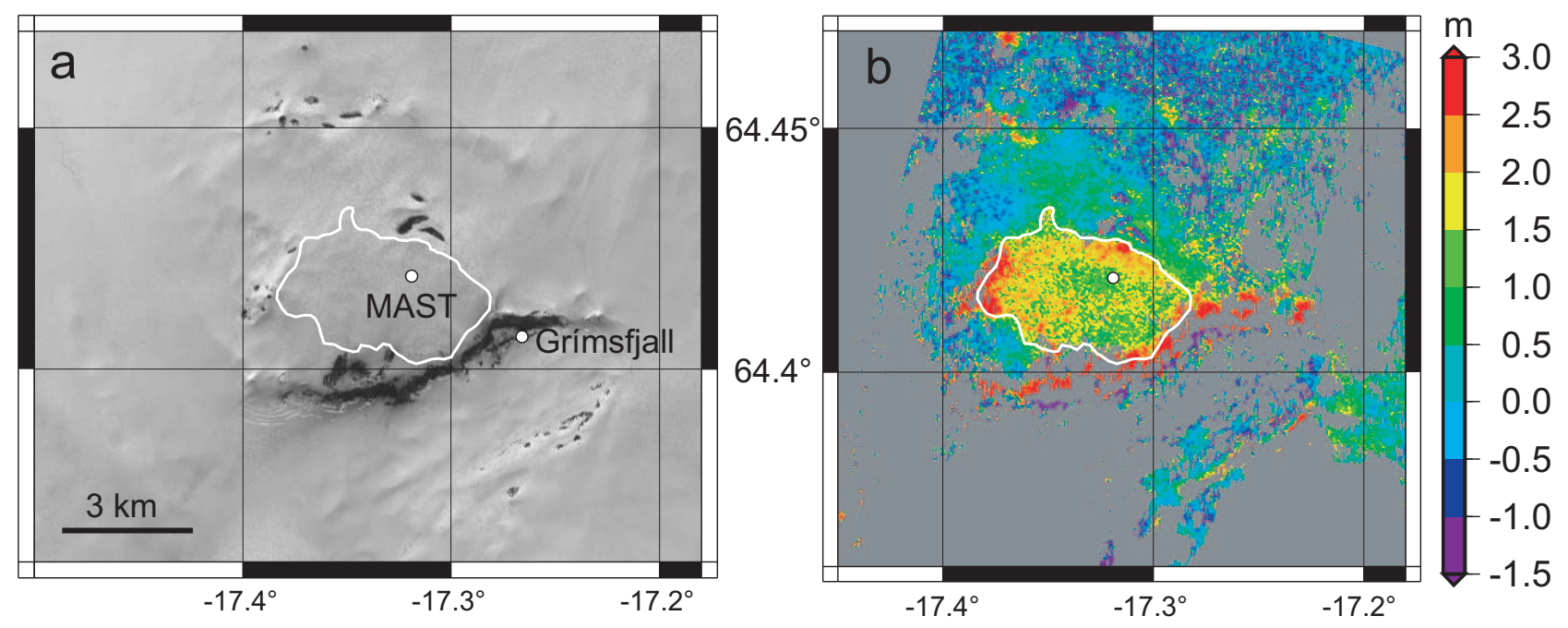

Fig. 5. (a) SPOT5 image of the Grímsvötn caldera acquired the 16 August 2004. The extent of the subglacial lake (white line) has been derived from the map of the uplift. The mean uplift of the ice shelf during 5 days, $1.7 \mathrm{~m}$, is estimated within this limit. The GPS station (MAST) on the floating ice shelf and the Grímsfjall mountain are located. (b) Map of the uplift of the Grímvötn ice shelf between the 11 and 16 August 2004. In grey, pixels were the correlation failed. 


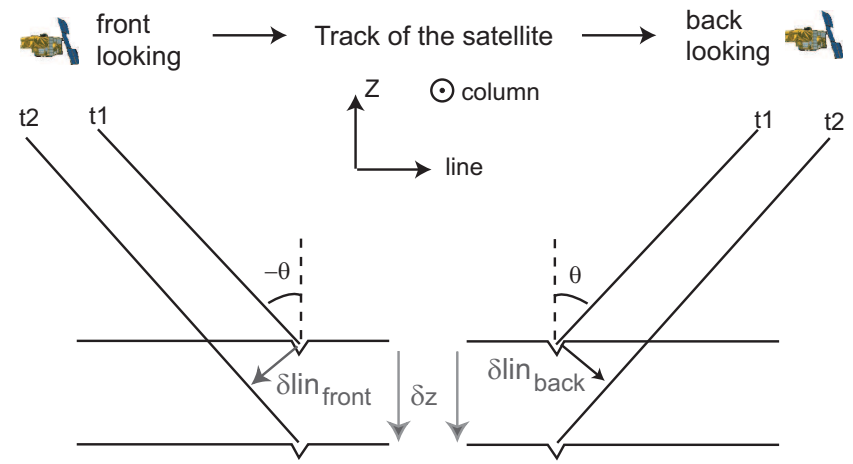

Fig. 6. A potential satellite configuration for mapping the three-dimensional displacement field of the Earth's surface. We assume an along-track stereo capability similar to the HRS system on-board the SPOT5 satellite. During the first pass of the satellite $\left(t_{1}\right)$, two images are acquired along the track of the satellite from foreand aft- looking sensors. One orbital cycle later during the second pass $\left(t_{2}\right)$, two more scenes are acquired. By correlating the images acquired from a similar point of view, one can deduce all three components of the displacement field (here the displacement of a crevasse on the surface of a glacier). Note that this figure is drawn in a vertical plane that contains the track of the satellite and lies perpendicular to the plane used in Figure 3 because we consider the case of a sensor with along-track stereo capabilities (such as ASTER or HRS or HRS-C on-board Mars Express (33)). The results presented in this article are based on the HRG sensor on board SPOT5 with across-track stereo capabilities. 